\title{
AVOIDABLE DELAY IN THE TRIAL COURTS
}

Delay in the administration of justice is the frequent subject of discussion in the newspapers, in magazines and in meetings of lawyers. In a message of the President of the United States to Congress it was said:

"I would like to call attention to the very unsatisfactory state of our criminal law, resulting in large part from the habit of setting aside the judgments of inferior courts on technicalities absolutely unconnected with the merits of the case, and where there is no attempt to show that there has been any failure of substantial justice. It would be well to enact a law providing something to the effect that: 'No judgment shall be set aside or new trial granted in any cause, civil or criminal, on the ground of misdirection of the jury, or the improper admission or rejection of evidence, or for error as to any matter of pleading or procedure, unless in the opinion of the Court to which the application is made, after an examination of the entire cause, it shall affirmatively appear that the error complained of has resulted in a miscarriage of justice." "

An eminent Statesman, Jurist and Diplomat who is likely to be the next President of the United States, is reported to have said before the State Bar Association of Virginia, that he believed the greatest question before the American people is the improvement in the administration of justice, civil and criminal.

It is not well to magnify the evils of society. It does not cure them to do so. The generalizations quoted are demonstrable exaggerations. Coming from such sources, the tendency is to increase disrespect for the courts, which is now altogether too common. It should not be forgotten at the outset that comparatively few people find it necessary to resort to the courts in order to settle their differences. When it is found necessary to commence litigation, nearly all the cases are speedily tried and judgments rendered therein regarded as final.

In a recent address before the Michigan Association of Judges, made by its then President, Judge Daboll, it was stated, after collecting the official figures, that the Circuit Courts of Michigan, which are the trial courts of record in that State, tried each year about seven thousand three huindred cases; of these about six 
hundred find their way to the Supreme Court, which in that State is the court of last resort. Less than two hundred of the six hundred cases were reversed, indicating that the Circuit Courts of that State are courts of last resort in eighty-eight per cent of all cases tried before them, and their judgments are final in ninetyfive per cent of the cases passed upon by them. There is reason to suppose that a like result exists in the other States.

In a series of articles published in the Outlook in Igo6, George Whitney Moore, of Detroit, who had gathered from the official reports the statistics, demonstrated that in the States of New York, Indiana, Towa, Wisconsin, Minnesota, Michigan, Illinois, and North Dakota, having a population of $26,500,000$, there were of criminal cases in the courts of last resort, yearly, affirmed, ninety-one, reversed and dismissed, nine, reversed and new trials ordered, twenty-nine; or stated another way, one new trial each year was ordered for about one million of people. The total number of new trials allowed in criminal appeals in the Court of Appeals of New York, for the year 1904, was ten in a population of eight millions of people.

The official reports for the same year of the criminal appeals from the United States District Courts to the United States Courts of Appeals show there were but eight new trials granted for the entire United States.

The statistics gathered by Mr. Moore also show that in Michigan, Wisconsin, Iowa, Minnesota and North Dakota, States having no intermediate courts, the new trials granted in criminal cases for the ten years preceding 1900 , were each year approximately two and one-half for each million of population, for the five years ending with 1904, there were one and two-tenths, and for the year I904 alone, was ninety-five one hundredths of one case for each million of population, a reduction of over one-half in fifteen years. In nearly all these cases new trials were granted for reasons recognized by all good lawyers as necessary ones. In most of the cases, a denial of new trials would have been a denial of justice.

In the current number of Law Notes, Mr. Thomas J. Johnson has an article of considerable length giving figures in detail which he summarizes as follows:

"Thus we see that, with I45,55 I cases of many kinds, criminal, admiralty, jury, equity (distributed over the entire United States in the Federal Courts and the State Courts of Vermont, New 
York, Indiana, North Dakota, Alabama, Louisiana, and Washington, surely a widely distributed and representative selection) there were only 3,IOI appeals taken from judgments of the courts of first instance; and only 754 reversals. These percentages are respectively 2.13 , and 0.518 . In other words, about one case in one hundred and ninety-three (I93.04) was reversed."

In view of these figures which are recent and authentic, we think it an exaggeration to say that the delay in the administration of justice is the greatest question before the American people. The statistics demonstrate a wonderfully efficient and safe administration of the law, both civil and criminal.

The matter of expense, so far as it relates to nearly all the State Courts is not oppressive. It is difficult to see how it could be very much cheapened. The criticism as to the Federal Courts seems to be well taken. The expense attending the taking of appeals is oppressive. The modification of two or three rules of court adopted a long time ago when conditions were very different from now, would afford a substantial remedy.

In the case of People v. Murray, 52 Mich. 291, Justice Cooley, speaking for all the justices except one, said: "I shall always be ready to preserve in its integrity every constitutional right, but $I$ do not understand that the Constitution is an instrument to play fast and loose with in criminal cases, any more than in any other, or that it is the business of the courts to be astute in the discovery of technical difficulties in the punishment of parties, for their criminal conduct." The above has been the spirit in which the criminal law has been administered, not only in the Michigan courts, but in the trial courts of the country generally.

It may be conceded, however, that there are unnecessary delays in some cases, and as delays in the administration of justice frequently work as great hardship as denials of justice, it may be well to consider some of the causes of avoidable delays, and, if possible, suggests some remedies that are workable.

It is sometimes said that matter of pleadings is responsible for delays. Where the common law procedure prevails, the adoption of a code is urged as a remedy, while in some of the code states a remedy is soukht through frequent amendments to the code. In nearly all the States having the common law procedure there are liberal statutes of amendment. The preparation of the pleadings under either method of procedure is not a difficult task, and is not beyond the capacity of any one having sufficient ability to warrant 
his admission to the profession of the law. It is seldom that a case fails because of the pleadings, and the delays arising from that source are inconsequential.

Other critics would have the avoidable delays attributed to the system of jury trials. In a very able paper read before the American Bar Association, the late Alfred Russell said very severe things of jury trials. To quote from him briefly, he said: "What may be deemed the second principal cause, and perhaps, indeed, the chief cause of delay and uncertainty in our courts is the jury system in civil cases." . . . . . "In its existing practical operation, it would seem as if the jury system, in civil causes, were purposely contrived to produce delay and uncertainty. . . . . The jury is an illustration of what John Stuart Mills calls, the influence of obsolete institutions on modern ideas, and which he says 'perpetuate in many of the greatest concerns of life, mitigated barbarism." Mr. Russell adds, "The jury, to my mind, is one of those things. Suitors with honest causes now avoid juries as a general rule, if possible, but with an ill cause almost invariably demand a jury, and it is proverbial, that before a jury you gain the causes you expect to lose, and lose those you expect to gain." As might be expected, Mr. Russell, having this view of the jury system, advised that in civil causes it be done away with wholly. This criticism, so far as it applies to jury trials in the courts away from the large cities, is not true. It is too sweeping a generalization to be true of any trial courts. If it has a basis of truth in the large cities the remedy is to be found, not in a condemnation of the system itself, but in a reform of the method of administration.

Twenty-five years of observation in the trial courts as lawyer and judge, has afforded an opportunity to know something of the judges who preside over them, and the juries who decide causes, especially in the counties away from the large cities. The judges are but men; they have their prejudices, their passions, their friends, and some of them their enemies; and while they are honest men, they are less likely to properly determine a question of fact than twelve men who are selected from the ordinary walks of life, and who deal daily with ordinary facts of life. It is better for the judges and for the parties that controverted questions of fact should be passed upon by men who have been selected from the body of the people. The judgment upon a question of fact of twelve ordinary jurors, selected according to the provisions of 
law, is more likely to be correct than the judgment of any judge, however honest or impartial he may be. The jury system will continue to be a part of our system of court procedure for a long time to come, and our efforts should be directed to the correction of such abuses as exist that it may become what it was intended to be, an ideal method for the determination of questions of fact.

In nearly all of the States, it is provided in substance that a list of names of suitable persons shall be prepared from which jurors may be obtained, who shall have the qualifications of electors, and, in making such selections, the names of such only as are not exempt from serving on juries who are in possession of their natural faculties, and not infirm or decrepit, of good character, of approved integrity, of sound judgment, and well informed, and conversant with the English language.

If for any reason a court should find itself with a list of names not selected in accordance with the law, it should call the attention of the officers whose duty it is to select the names, to the provisions of law and urge a compliance with its terms. If an individual juror is clearly shown to not have the qualifications mentioned in the law, he should be excused for the term. On the other hand, when a properly qualified juror is drawn, he should not be excused simply because he wants to be excused for business or other reasons. Many people think because they have important business interests they should not be called upon for jury service, and will, for that reason, plead to be excused; such plea ought not to be granted except in extreme cases.

To serve upon juries when legally called to do so is an indication of good citizenship: The wealthy and the busy man ought to be willing to serve in this capacity, and when not willing should be required to do so. It will frequently be found useful when the jurors are assembled, for the judge briefly to instruct them upon their duties and especially upon their importance. Emphasis should be given to the proposition that litigants are in court because they could not themselves settle their differences; that in order to have a case ended, a verdict is essential, that the jurors should go to the jury room, not in the character of disputants, but with the idea of harmonizing the evidence so far as possible, and where they cannot do so, to consider it all without prejudice and determine what the preponderance thereof establishes. If the judge can imbue the jurors with the proper spirit which should 
actuate them in the discharge of their duties, a disagreement will seldom occur.

It is a fortunate thing in the administration of the criminal business of the trial courts when the interests of the people are looked after by an able, honest, intelligent and industrious prosecuting officer; such a man reduces the avoidable delays in the trial of criminal causes to the minimum. An example may be found in an adjoining circuit of a prosecuting officer who, during his term of office, tried one hundred and thirty-six criminal cases; he had them so well prepared that he secured one hundred and thirty-two convictions; they were so fairly tried but one of them was reversed on appeal to the Supreme Court.

If the causes of delay to which reference has been made, could be entirely eliminated there would still be no considerable relief from avoidable causes of delay. In the last analysis it will be found that the judges must be held responsible. Where there is an intelligent, efficient administration of the business of the Court there are no avoidable causes of delay, and this is the normal condition in most Trial Courts. Where the business of the Court is found to accumulate until the Court is getting buried beneath its accumulations, it will be found, as a rule, that the trouble is with the judge. Not every good lawyer will make a good trial judge. Not only must he be learned in the law, honest and industrious, but he must be possessed of tact, courage, good common sense and executive ability of a high order, that the business of the Court shall be kept moving. In most Trial Courts it is advisable to have the jury summoned for the second day of the term; this enables the first day of the term to be given up to the arraignment of criminals and the hearing of the various motions that are so plentiful always, on the first day of the term and which makes the first day of the term the busiest one of them all. It has the added advantage of having the jurors absent during the discussion of questions which relate to causes that may be tried before them later; it also saves very considerable expense.

It is a matter of essential importance that the journal should be written when the facts surrounding the trial are all fresh in the minds of the Court and counsel. The journal should be signed regularly, preferably every morning after reading. Continuances should not be granted as of course, but counsel should be given to understand they must get their causes ready for trial. The lawyers will soon learn the temper of the judge in this respect 
and will have their cases ready. On the second day of the term, at the conclusion of the reading of the journal, there should be the same condition of order in the court room that is to be found in a well regulated business establishment, and that should be the normal condition of the court room during the transaction of all its business.

While the counsel are selecting the jury, the judge should be examining the files and pleadings in the case. If he is at all clever he can do this and listen to the counsel. By the time the opening address has been made, the Court ought to be familiar enough with the case, and how it is likely to develop, so that he can pass quickly and intelligently upon the admission of the evidence offered. Questions arising upon the admission of evidence should be disposed of with great promptness, and as a rule, without argument.

If the judge is in doubt as to the competency of the evidence, a few direct questions put to counsel will draw out what is proposed, enabling the judge to pass intelligently upon the question and the case should move on quickly.

During the taking of the evidence, if the judge is as familiar with the digests and decisions of the court of last resort in his State, as he ought to be, he will have at his disposal its decisions bearing upon the case at trial. If this is done, as a rule, the legal argument will be very brief. The judge should always be willing to listen to counsel, but he should not allow a long argument upon a legal question where the law is well settled.

The charge to the jury is, perhaps, the most important function performed by a trial judge; it should never be a legal essay, and it should never be addressed to spectators in the court room. Preferably, it should be an oral charge, but that will depend upon temperament and habits of thought; every judge must decide for himself, where the statute does not decide for him. The charge should be short, clear and positive in its character, dealing only with such legal questions as are involved in the case at issue; it should be clothed in language as terse, simple and direct as is at the command of the judge, and if the jury has that confidence in the judge which he ought to be able to inspire, it will accept implicitly his statements as to the law which should govern them.

It is the duty of the lawyers to maintain toward the Courts a respectful manner. Stated in the language of one of the canons approved by the American Bar Association: "Clients, not law- 
yers, are the litigants. Whatever may be the ill-feeling existing between clients, it should not be allowed to influence counsel in their conduct and demeanor toward each other or toward suitors in the case. All personalities between counsel should be scrupulously avoided. In the trial of a cause, it is indecent to allude to the personal history or the personal peculiarities and idiosyncrasies of counsel on the other side. Personal colloquies between counsel which cause delay and promote unseemly wrangling, should also be carefully avoided."

Nearly all lawyers are desirous of observing these duties. If any lawyer is not inclined to do so, he should be obliged to do so by the Court. In requiring him to do this, the judge will rise in the esteem of the lawyer offending, and the offense is not likely to be repeated.

Another phase of court work demands attention. Some lawyers who, in fact, desire a jury, never ask for one, hoping the trial judge will order a jury where questions of fact are involved; such lawyers ought to be disappointed. While it is not pleasant for a trial judge to dispose of issues of fact, it is a duty he ought not to avoid. With the aid of the shorthand reporter he can determine questions of fact and issues of law without very great delay.

There is a branch of the law which in its administration will justify many of the complaints of delay. These are the chancery causes. The chancery rules provide for the commencement, the preparation and the final disposition of a chancery case, within reasonable limits, but the practical working of the system is now too often that contested chancery cases are carried on interminably. Indeed, the celebrated case of Jarndyce v. Jarndyce, is not without parallel in this country. Chancery cases may be found commenced so long ago that the attorneys who brought them can hardly remember when they were instituted.

The practice that prevails among many judges of taking the files in chancery cases home with them, after the case has been argued at length, is to be greatly deprecated. There is no time, as a rule, when the judge is so well prepared to dispose of a case, as just after he has heard all the testimony and has had the benefit of the arguments of counsel, who have made themselves familiar with the strong points of their case from their respective standpoints. If there should be some controverted questicn, either of fact or law, that the judge desires to take a little time to 
determine, he should embrace the frrst opportunity to dispose of it, and, under no circumstances, should he allow the case to go undecided longer than during the session of the term. If he allows the cases to accumulate, he will soon be overwhelmed with doubt as to their disposition, and the doubt will grow, making the decision more and more difficult. The cases heard in one term should be decided before another term is begun, and all the journal entries should be properly made and signed, so that if death should come to the trial judge suddenly, as some of us hope it may, when it comes at all, then there will be no unfinished business for his successor to do over again, because of the neglect of duty upon his part.

The observations offered in this paper are commonplace, but they are the result of many years' experience in the courts as practitioner and judge, and it is believed they may be useful, at least to some of the younger judges, and may help to remedy avoidable delays in Trial Courts.

Joseph B. Moore. 